\title{
Land-use changes influence soil bacterial communities in a meadow grassland in Northeast China
}

\author{
Chengyou Cao, Ying Zhang, Wei Qian, Caiping Liang, Congmin Wang, and Shuang Tao \\ College of Life and Health Sciences, Northeastern University, Shenyang 110169, People's Republic China \\ Correspondence to: Chengyou Cao (caochengyou@mail.neu.edu.cn)
}

Received: 3 July 2017 - Discussion started: 19 July 2017

Revised: 12 September 2017 - Accepted: 24 September 2017 - Published: 26 October 2017

\begin{abstract}
The conversion of natural grassland into agricultural fields is an intensive anthropogenic perturbation commonly occurring in semiarid regions, and this perturbation strongly affects soil microbiota. In this study, the influences of land-use conversion on the soil properties and bacterial communities in the Horqin Grasslands in Northeast China were assessed. This study aimed to investigate (1) how the abundances of soil bacteria changed across land-use types, (2) how the structure of the soil bacterial community was altered in each land-use type, and (3) how these variations were correlated with soil physical and chemical properties. Variations in the diversities and compositions of bacterial communities and the relative abundances of dominant taxa were detected in four distinct land-use systems, namely, natural meadow grassland, paddy field, upland field, and poplar plantation, through the high-throughput Illumina MiSeq sequencing technique. The results indicated that landuse changes primarily affected the soil physical and chemical properties and bacterial community structure. Soil properties, namely, organic matter, $\mathrm{pH}$, total $\mathrm{N}$, total $\mathrm{P}$, available $\mathrm{N}$ and $\mathrm{P}$, and microbial biomass $\mathrm{C}, \mathrm{N}$, and $\mathrm{P}$, influenced the bacterial community structure. The dominant phyla and genera were almost the same among the land-use types, but their relative abundances were significantly different. The effects of land-use changes on the structure of soil bacterial communities were more quantitative than qualitative.
\end{abstract}

\section{Introduction}

Land-use conversion, habitat destruction, climate change, and other intensive anthropogenic activities strongly alter natural ecosystems (Pabst et al., 2013). Over $38 \%$ of all natural landscapes worldwide have been converted to managed systems (Holland et al., 2016). Thus, ecological processes in the conversions should be elucidated to predict the development and sustainability of ecosystem services. Arid and semiarid areas account for $30 \%$ of the total land area worldwide (Ran et al., 2014). These areas are also known for their ecological fragility and resource specificity. The conversion of natural grassland into agricultural fields is a dominant human perturbation commonly occurring in semiarid areas. In the western part of Northeast China, large grassland areas have been converted to upland fields or paddy fields because of high income from farming. This conversion can cause progressive and cumulative soil disturbances and is thus considered a key factor that affects land desertification development, reduces biodiversity, and alters ecological processes in terrestrial ecosystems (Sala et al., 2000). Intensive soil perturbations can also change intrinsic soil properties by promoting soil nutrient cycles and modifying soil physical, chemical, and microbiological properties and the structures of dwelling microbial communities in local ecosystems (Lauber et al., 2008; Lin et al., 2011, 2013; Kuramae et al., 2012). Therefore, land-use or land-cover change is an important factor affecting soil quality. Soil microbial diversity and community structure function as sensitive indicators of soil health and quality and hence rapidly respond to land-use conversions (He et al., 2008).

The effects of land-use conversion on soil physical, chemical, and microbiological properties have been comprehensively investigated. Land-use conversion can elicit significant and long-term effects on the moisture, texture, aeration, $\mathrm{pH}$, nutrient status, microbial biomass, and enzymatic activities of soil largely because of the changes in plant community composition and different management practices across 
land-use types (Murty et al., 2002; Nishimura et al., 2008; Rahman et al., 2008; Wallenius et al., 2011). However, the effects of land-use conversion on soil biology have not yet been sufficiently assessed. Although land-use conversion has been confirmed to affect the structure of soil microbial communities significantly (Steenwerth et al., 2002; Johnson et al., 2003; Lauber et al., 2008), changes in the abundance of soil-specific taxonomic groups modified during land-use conversion and alterations in plant cover and soil properties remain poorly understood. Soil microbial communities are structured by climate, geology, land use, and soil physical and chemical factors, such as soil organic matter, porosity, and $\mathrm{pH}$ (Thomson et al., 2010, 2015; Griffiths et al., 2011; Hartmann et al., 2012). Land-use conversion may lead to unfavorable modification of several environmental variables, which can indirectly or directly affect soil microbial diversity. Therefore, the consequences of changes in soil microbial diversity and community structure during land-use conversion should be investigated to provide relevant information on microbial responses to changes in the soil environment and interactions between soil microbial communities and soil physical and chemical properties.

Culture-independent techniques, such as phospholipid fatty acid biomarkers, polymerase chain reaction-denaturing gradient gel electrophoresis, clone libraries, fluorescence in situ hybridization, enterobacterial repetitive intergenic consensus, and terminal restriction fragment length polymorphism, have been widely employed to examine soil microbial community changes as a consequence of land-cover change, soil pollution, and fertilization (Baath et al., 2003; He et al., 2007; Berg et al., 2012; Suleiman et al., 2013; Thomson et al., 2015). However, these techniques yield unsatisfactory performances in terms of the accurate detection of the changes in ecologically important soil microbial groups under different soil environmental conditions because of resolution limits, fingerprint complexity, and highly abundant indigenous microbes in soil (Bruce et al., 2000; Quince et al., 2009). Conversely, DNA-characterization-based highthroughput methodologies, such as sequencing and subsequent sequence alignment, can directly detect microbial community composition and variations in species with low richness (Shi et al., 2014; Zhao et al., 2014). These methodologies have also been widely adopted to assess the genetic structure and diversity of microbial communities in various environments (Quince et al., 2009; Golebiewski et al., 2014; Liu et al., 2014; Portune et al., 2014; Ren et al., 2014; Singh et al., 2014; Thomson et al., 2015).

Considering the increasing number of reclamation activities in native meadow grasslands in Northeast China, we applied Illumina MiSeq sequencing to investigate the changes in the diversities, compositions, and relative abundances of the dominant taxa of soil bacterial communities in native meadow grassland and adjacent upland fields, paddy fields, and woodland habitats. We then classified the microbial species and compared their structures among different land- use types. We also analyzed the correlation of specific microbial phyla with soil physical and chemical properties. Thus, we could obtain relevant data to enhance our understanding of the effects of the use change of native grassland on soil microbiota and provide useful information for the sustainable use of ecosystem services in fragile grasslands. We also statistically analyzed our data to evaluate the differences in the structures of soil bacterial communities among different land-use types and to determine their correlations with soil physical and chemical properties. We hypothesized that soil bacterial communities respond to land-use conversion, and these responses are related to variations in soil properties induced by different management measures during changes. This study aimed (1) to determine the changes in the abundances of soil bacteria across land-use types, (2) to identify the alterations in the structure of soil microbial communities in each land-use type, and (3) to observe the responses of specific microbial groups to land-use changes and the correlation of these variations with soil physical and chemical properties.

\section{Materials and methods}

\subsection{Study location and site description}

This study was conducted at the Wulanaodu Experimental Station of Desertification $\left(43^{\circ} 02^{\prime} \mathrm{N}, 119^{\circ} 39^{\prime} \mathrm{E}\right)$ under the Institute of Applied Ecology, Chinese Academy of Sciences. The station is located in the western part of the Horqin Grasslands in Northeast China. The Wulanaodu region is located in the temperate zone and thus has a continental semiarid monsoon climate with mean annual precipitation of approximately $284.4 \mathrm{~mm}$. In addition, $70-80 \%$ of the precipitation occurs from May to September. The annual average temperature and wind velocity in the area are $6.3{ }^{\circ} \mathrm{C}$ and $4.4 \mathrm{~m} \mathrm{~s}^{-1}$, respectively. The soils are classified as alkali meadow soil. The landscape is characterized by a mosaic of gently undulating sand dunes and interdune meadow grassland (Zhang et al., 2016). The original vegetation belongs to the Mongolian flora, which mainly includes Aneurolepidium chinense Kitag., Chenopodium acuminatum Willd., Bassia dasyphylla O. Kuntze, Lespedeza davurica Schindl., Thermopsis lanceolata R. Br., Achnatherum cristatum Gaertner, Arundinella hirta C. Tanaka, Caragana microphylla Lam., Salix mongolica Siuzev, Spodiopogon sibiricus Trin., and Artemisia frigida Willd. (Cao et al., 2008). Most of the herbaceous plant species in this region are distributed in the meadow grassland. Furthermore, a large native meadow grassland lies in the Wulanaodu region and supports the production of local animal husbandry. The meadow grassland is typically used as clipping pastures, which are enclosed during the growing season (from April to late September) and openly grazed after the grasses are harvested (Zhang et al., 2015). In recent decades, the grasslands have been seriously degraded 
because of climate change, overgrazing, and the aridification of the habitat (Cao et al., 2006); a vast area of the degraded meadow grasslands was converted to farmland. At present, a mosaic of grassland, paddy fields, upland fields, and woodland can be observed in the Wulanaodu region, and these ecosystems can be used to study the response of soil microbial community structures to land-use conversion.

\subsection{Experimental design and soil sampling}

The soils were sampled in May 2016. An adjacent native meadow grassland, a 26-year paddy field (Oryza sativa L.), a 50-year upland field (Zea mays L.), and a 34-year poplar plantation (designated as NMG, PF, UF, and PP, respectively) were selected as experimental sites. PF, UF, and PP were all converted from NMG, and thus the soil types were the same. NMG was openly grazed except for the growing season. At $\mathrm{PF}$ and UF sites, urea, $\left(\mathrm{NH}_{4}\right)_{2} \mathrm{HPO}_{4}$, and $\mathrm{KCl}$ were annually applied during maize seeding, rice transplanting, and crop growth. The averages of height and diameter at the breast height of the trees were $18.5 \mathrm{~m}$ and $20.6 \mathrm{~cm}$ at the PP site, respectively. In each site, three $30 \mathrm{~m} \times 30 \mathrm{~m}$ plots were installed for sampling, and each plot was $300 \mathrm{~m}$ away from the other plots. Approximately $0-10 \mathrm{~cm}$ soil samples were collected. All the samples were sieved in the field using a $2 \mathrm{~mm}$ screen. Half of each sample was immediately frozen at $-80^{\circ} \mathrm{C}$ for DNA extraction, while the other half of the sample was used for the analysis of the chemical and physical properties.

\subsection{Soil physical and chemical properties and microbial biomass}

Soil water content was determined gravimetrically by drying the soil at $105^{\circ} \mathrm{C}$ for $24 \mathrm{~h}$. In the laboratory, the air-dried soil was ground to pass through a $2.0 \mathrm{~mm}$ mesh and was then analyzed for electrical conductivity (EC; $1: 5$ soil to water ratio), $\mathrm{pH}(1: 2.5$ soil to water ratio), total $\mathrm{K}$, and available $\mathrm{N}$, P, and $\mathrm{K}$. The soil organic matter (SOM), total N, and total $\mathrm{P}$ of the samples ground to pass through a $0.25 \mathrm{~mm}$ mesh were analyzed. Subsequently, the amount of organic matter, total $\mathrm{N}$, total $\mathrm{P}$, available $\mathrm{N}$, and available $\mathrm{P}$ were analyzed through the $\mathrm{K}_{2} \mathrm{Cr}_{2} \mathrm{O}_{7}-\mathrm{H}_{2} \mathrm{SO}_{4}$ oxidation method, semimicroKjedahl digestion method, acid-digestion molybdate colorimetric method, alkaline diffusion method, and molybdate ascorbic acid method (in $0.5 \mathrm{M} \mathrm{NaHCO}_{3}$ ), respectively. All the analyses were performed according to the procedures described in ISSCAS (1978). The C and $\mathrm{N}$ in the soil microbial biomass were estimated through the chloroform fumigationincubation method (Jenkinson and Powlson, 1976). The P in the microbial biomass was analyzed according to the methods described by Brookes et al. (1982).

\subsection{DNA extraction, PCR amplification, and 16S rDNA sequencing}

Microbial DNA was extracted from $0.3 \mathrm{~g}$ of fresh soil sample using a soil DNA extraction kit (Tiangen Biotech, China) according to the manufacturer instructions. The 16S rRNA genes were amplified using the bar code primers $341 \mathrm{~F}$ and 805R (Hugerth et al., 2014). The $50 \mu \mathrm{L}$ PCR mixture contained $5 \mu \mathrm{L}$ of $10 \times$ reaction buffer, $10 \mathrm{ng}$ of template DNA, $0.5 \mu \mathrm{L}$ of $10 \mathrm{mM}$ dNTPs, $0.5 \mu \mathrm{L}$ of $50 \mu \mathrm{M}$ each primer, and $0.5 \mu \mathrm{L}$ of $5 \mathrm{U}_{\mu \mathrm{L}^{-1}}$ Platinum Taq polymerase. PCR was performed using the following program: $94^{\circ} \mathrm{C}$ for $3 \mathrm{~min} ; 5 \mathrm{cy}$ cles of $94^{\circ} \mathrm{C}$ for $30 \mathrm{~s}, 45^{\circ} \mathrm{C}$ for $20 \mathrm{~s}, 72^{\circ} \mathrm{C}$ for $30 \mathrm{~s} ; 20 \mathrm{cy}-$ cles of $94^{\circ} \mathrm{C}$ for $20 \mathrm{~s}, 55^{\circ} \mathrm{C}$ for $20 \mathrm{~s}, 72^{\circ} \mathrm{C}$ for $30 \mathrm{~s}$; and a final extension at $72^{\circ} \mathrm{C}$ for $10 \mathrm{~min}$. The PCR products were purified using the agarose gel extraction kit (Tiangen Biotech, China) according to the manufacturer instructions and then quantified using a Qubit 2.0 fluorometer. The purified PCR products of all the samples were mixed in equal mole amounts and sequenced on an Illumina MiSeq platform (Genewiz Biotechnology Co., Ltd, Suzhou, China) according to the standard protocols.

\subsection{Processing and analyzing of sequencing data}

Raw sequence files were analyzed and quality filtered using the Quantitative Insights Into Microbial Ecology (QIIME version 1.17; http://qiime.org). Reads shorter than $200 \mathrm{bp}$ and average quality scores $<25$ were discarded. The chimeric sequences were then identified and removed using the UCHIME software (http://drive5.com/uchime). The operational taxonomic units (OTUs) with $97 \%$ similarity cutoff were clustered using UPARSE (version 7.1; http://drive5. com/uparse). The representative sequences of each OTU were taxonomically classified using the ribosomal database project (RDP) naive Bayesian 16S rRNA classifier (Wang et al., 2007), which assigns the complete taxonomic information from domain to species to each sequence in the database with $80 \%$ taxonomy confidence and an $e$ value of 0.001 . OTU richness analysis was conducted using Mothur software (https://www.mothur.org; version 1.21.1), and the alpha diversity indices, including the Shannon-Wiener index (SW), Chao's species richness estimator (Chao), and the abundance-based coverage estimator (ACE), were calculated (Schloss et al., 2009). Heat map analysis was performed using $\mathrm{MeV}$ version 4.2. The Bray-Curtis dissimilarity measure was performed to calculate the between-sample similarity matrix, and principal coordinate analysis (PCoA) was performed to compare and visualize the similarities among the soil samples. All raw sequences were submitted to the NCBI Sequence Read Archive under the accession number SRR5083094- SRR5083105.

ANOVA and multiple comparisons were performed to determine the differences among the land-use types. All the statistical analyses were performed using the SPSS software 
package (version 13.0; SPSS Co., Ltd, Chicago, USA). A difference at $P<0.05$ was considered to be statistically significant.

\subsection{Canonical correspondence analysis}

Canonical correspondence analysis (CCA) was performed using CANOCO 4.5 (Biometris, Wageningen, the Netherlands) to determine the soil chemical properties that have the most significant effect on the composition of the soil microbial community. The correlations of the soil parameters were examined using Monte Carlo permutation, and the figures were generated by CanoDraw 4.0 (Biometris Plant Research International, Wageningen, the Netherlands).

\section{Results}

\subsection{Soil physical and chemical parameters}

The physical and chemical properties and microbial biomass $(\mathrm{C}, \mathrm{N}$, and $\mathrm{P})$ of the soil varied according to land use. Significant differences in the soil moisture, $\mathrm{pH}, \mathrm{EC}, \mathrm{SOM}$, total $\mathrm{N}$, available $\mathrm{P}$, and microbial $\mathrm{C}, \mathrm{N}$, and $\mathrm{P}$ among the land-use types were observed (Table $1 ; P<0.05$ ). Meanwhile, no significant difference in soil total $\mathrm{P}$ and available $\mathrm{N}$ among the samples was observed. The conversions from native meadow grassland to UF, PF, or PP significantly decreased the soil $\mathrm{pH}$ and increased the EC and available P. The SOM, total N, and microbial $\mathrm{C}$ were lower in UF and PF, but higher in PP than those in NMG, respectively: $\mathrm{PP}>\mathrm{NMG}>\mathrm{UF}>\mathrm{PF}$.

\subsection{Sequencing results and diversity indices}

A total of 646127 valid sequences and 87428 OTUs were obtained from the 12 samples through MiSeq sequencing analysis. Each sample contained 4.0441 to 6.6811 reads and had different phylogenetic OTUs ranging from 6.114 to 8.744 using a $3 \%$ nucleotide cutoff (Table 2). In addition, the indices of the alpha diversity, including Chao, SW, coverage, and ACE, were also calculated to estimate the species richness and biodiversity in the 12 samples. Significant differences in the mean values of ACE, Chao, and SW index among the land-use types were observed (Table 2; $P<0.05$ ). The average values of the ACE and Chao in PF were significantly lower than in the NMG, UF, and PP, while its value on the SW index was higher than those in NMG and PP. The coverage index, ranged from 0.93 to 0.96 , indicated that significant differences among the samples were absent. PCoA was performed according to the Bray-Curtis distance matrix (Fig. 1). The PCoA plot showed that the microbial communities from the NMG and PP grouped together, and UF1-UF3 and PF1-PF3 separately formed other groups. These findings indicated that land-use type can alter the soil microbial communities, but it is not the only determinant.

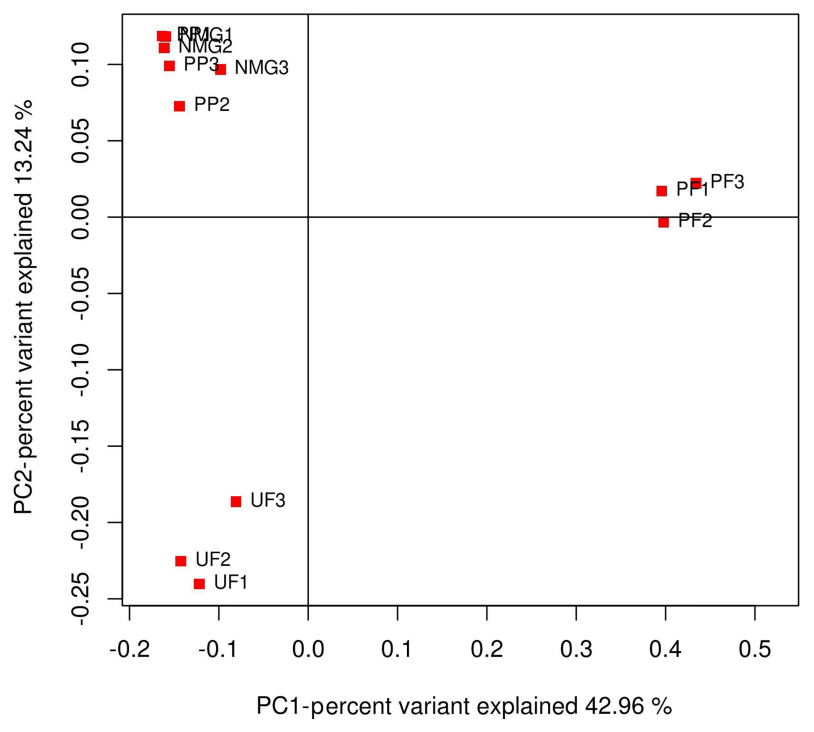

Figure 1. Ordination plot showing the grouping of soil bacterial communities according to PCoA based on Bray-Curtis distance matrix. NMG: native meadow grassland; UF: 50-year upland field; PF: 26-year paddy field; PP: 34-year poplar plantation.

\subsection{Taxonomic profiles}

The representative sequences of each OTU were assigned using the RDP classifier at the phylum, family, genus, and species level. The OTUs were classified into 46 different phyla, 416 orders, 776 families, 1289 genera, or 1801 species. Out of the 46 bacterial phyla, 13 dominant phyla with a relative abundance of $>1 \%$ were detected, and they include Proteobacteria, Acidobacteria, Actinobacteria, Bacteroidetes, Chloroflexi, Gemmatimonadetes, Firmicutes, Planctomycetes, Verrucomicrobia, Nitrospirae, Thaumarchaeota, Chlorobi, and candidate_division_TM7 in all the samples, which accounted for 92.48 to $97.68 \%$ of the total OTUs in the different samples. The average relative abundances of the top 30 phyla of the samples are shown in Fig. 2. The relative abundance of Proteobacteria ranged from $29.13 \%$ in PP to $30.50 \%$ in MS and was considered to be the dominant group in all the samples. Acidobacteria, Actinobacteria, Bacteroidetes, and Chloroflexi had higher relative abundances as well, and they ranged from 10.41 to 31.79 , 8.46 to $16.14,7.24$ to 12.56 , and 5.37 to $16.63 \%$, respectively. Four subdivisions of Proteobacteria $(\alpha, \beta, \gamma$, and $\delta$ Proteobacteria) were identified in all the libraries. Significant differences in the relative abundance of each subdivision among the land-use types were found (Fig. $3, P<0.05$ ), indicating the variations in the Proteobacteria phylum after landuse conversion. The $\alpha$-Proteobacteria had the highest relative abundance among the four subdivisions in all the samples and accounted for $11.14-13.82 \%$ of the total reads in the NMG and PP and $6.45-9.78 \%$ of the total reads in the PF and UF samples (Fig. 3). 
Table 1. Soil pH, EC, nutrients, and microbial biomass of samples (average of three replicates \pm SD).

\begin{tabular}{|c|c|c|c|c|c|c|}
\hline Items & NMG & UF & $\mathrm{PF}$ & PP & $P$ & $F$ \\
\hline Soil moisture $(\%)$ & $13.11 \pm 2.490 \mathrm{a}$ & $13.25 \pm 2.632 \mathrm{a}$ & $28.26 \pm 3.262 \mathrm{c}$ & $20.97 \pm 1.631 b$ & 23.803 & $<0.001$ \\
\hline $\mathrm{pH}$ & $8.67 \pm 0.200 b$ & $7.95 \pm 0.128 \mathrm{a}$ & $7.85 \pm 0.290 \mathrm{a}$ & $7.78 \pm 0.020 \mathrm{a}$ & 14.262 & 0.001 \\
\hline Electrical conductivity $\left(\mu \mathrm{S} \mathrm{cm}^{-1}\right)$ & $86.90 \pm 6.329 \mathrm{a}$ & $196.0 \pm 53.88 b$ & $111.2 \pm 33.11 \mathrm{a}$ & $306.0 \pm 14.91 \mathrm{c}$ & 27.631 & $<0.001$ \\
\hline Organic matter $\left(\mathrm{g} \mathrm{kg}^{-1}\right)$ & $4.186 \pm 0.064 b$ & $3.824 \pm 0.588 \mathrm{~b}$ & $1.589 \pm 0.130 \mathrm{a}$ & $4.579 \pm 0.097 \mathrm{c}$ & 57.251 & $<0.001$ \\
\hline Total N $\left(\mathrm{g} \mathrm{kg}^{-1}\right)$ & $0.103 \pm 0.005 \mathrm{c}$ & $0.084 \pm 0.006 \mathrm{~b}$ & $0.060 \pm 0.003 \mathrm{a}$ & $0.131 \pm 0.003 \mathrm{~d}$ & 136.790 & $<0.001$ \\
\hline Total $\mathrm{P}\left(\mathrm{g} \mathrm{kg}^{-1}\right)$ & $0.061 \pm 0.007 \mathrm{a}$ & $0.073 \pm 0.033 \mathrm{a}$ & $0.031 \pm 0.004 \mathrm{a}$ & $0.053 \pm 0.006 \mathrm{a}$ & 3.109 & 0.089 \\
\hline Available N ( $\left.\mathrm{mg} \mathrm{g}^{-1}\right)$ & $2.240 \pm 0.285 \mathrm{a}$ & $1.866 \pm 1.090 \mathrm{a}$ & $3.219 \pm 0.056 \mathrm{a}$ & $1.438 \pm 0.871 \mathrm{a}$ & 3.411 & 0.073 \\
\hline Available P (mg g $\left.{ }^{-1}\right)$ & $5.252 \pm 0.394 \mathrm{a}$ & $28.34 \pm 11.873 b$ & $12.20 \pm 3.034 \mathrm{a}$ & $7.457 \pm 1.643 \mathrm{a}$ & 8.532 & 0.007 \\
\hline Microbial biomass $\mathrm{C}\left(\mathrm{mg} \mathrm{kg}^{-1}\right)$ & $317.1 \pm 29.638 b$ & $96.84 \pm 3.646 \mathrm{a}$ & $76.32 \pm 2.279 \mathrm{a}$ & $466.6 \pm 34.71 \mathrm{c}$ & 199.019 & $<0.001$ \\
\hline Microbial biomass $\mathrm{N}\left(\mathrm{mg} \mathrm{kg}^{-1}\right)$ & $44.29 \pm 3.711 b$ & $17.28 \pm 3.014 \mathrm{a}$ & $83.40 \pm 9.679 c$ & $38.16 \pm 2.776 b$ & 73.646 & $<0.001$ \\
\hline Microbial biomass $\mathrm{P}\left(\mathrm{mg} \mathrm{kg}^{-1}\right)$ & $55.43 \pm 0.685 \mathrm{c}$ & $60.75 \pm 1.656 \mathrm{~d}$ & $19.23 \pm 0.698 \mathrm{a}$ & $26.68 \pm 2.524 b$ & 507.274 & $<0.001$ \\
\hline
\end{tabular}

NMG: native meadow grassland; UF: 50-year upland field; PF: 26-year paddy field; PP: 34-year poplar plantation. Means in the row followed by a different letter are significantly different $(P<0.05)$.

Table 2. MiSeq sequencing results and diversity estimates for each sampling site.

\begin{tabular}{|c|c|c|c|c|c|c|}
\hline \multirow[t]{2}{*}{ Sample } & \multicolumn{2}{|c|}{ Sequencing results } & \multicolumn{2}{|c|}{ Diversity estimates } & \multirow[b]{2}{*}{ SW } & \multirow[b]{2}{*}{ Coverage } \\
\hline & Total sequences & Total OTUs & ACE & Chao & & \\
\hline NMG1 & 62032 & 7298 & 6600 & 6345 & 10.15 & 0.94 \\
\hline NMG2 & 59445 & 7735 & 6695 & 6491 & 10.39 & 0.94 \\
\hline NMG3 & 52383 & 7691 & 7259 & 6988 & 10.62 & 0.93 \\
\hline Mean value & 57953 & 7575 & $6851 b$ & $6608 b$ & $10.39 \mathrm{a}$ & 0.94 \\
\hline UF1 & 40255 & 6114 & 6499 & 6286 & 10.49 & 0.94 \\
\hline UF2 & 53850 & 6825 & 6438 & 6236 & 10.46 & 0.94 \\
\hline UF3 & 58719 & 7401 & 6726 & 6555 & 10.55 & 0.94 \\
\hline Mean value & 50941 & 6780 & $6554 b$ & $6359 b$ & $10.50 \mathrm{ab}$ & 0.94 \\
\hline PF1 & 66811 & 8744 & 6137 & 6153 & 10.81 & 0.95 \\
\hline PF2 & 46571 & 7279 & 5999 & 5958 & 10.71 & 0.95 \\
\hline PF3 & 45213 & 6776 & 5342 & 5414 & 10.77 & 0.96 \\
\hline Mean value & 52865 & 7600 & $5826 a$ & $5842 \mathrm{a}$ & $10.76 b$ & 0.95 \\
\hline PP1 & 57894 & 7579 & 6515 & 6442 & 10.57 & 0.94 \\
\hline PP2 & 62513 & 7731 & 6771 & 6561 & 10.31 & 0.94 \\
\hline PP3 & 40441 & 6255 & 6860 & 6605 & 10.36 & 0.94 \\
\hline Mean value & 53616 & 7188 & $6715 b$ & $6536 b$ & $10.41 \mathrm{a}$ & 0.94 \\
\hline$F$ & - & - & 6.912 & 4.836 & 4.497 & - \\
\hline$P$ & - & - & 0.013 & 0.033 & 0.040 & - \\
\hline
\end{tabular}

ACE: abundance-based coverage estimator, Chao: Chao's species richness estimator, SW: Shannon-Wiener index. Species level, $97 \%$ similarity threshold used to define the OTUs. NMG: native meadow grassland; UF: 50-year upland field; PF:

26-year paddy field; PP: 34-year poplar plantation. Means in the column followed by a different letter are significantly different $(P<0.05)$.

\subsection{Core genera}

The dominant bacterial phyla in the soil samples were compared with one another at the genus levels to further reveal the changes in the soil microbial communities among the land-use types. In total, 1289 genera were identified in the 12 samples. The highest and lowest number of genera were found in the PF (1289) and PP (890) samples. Most of genera were commonly distributed in all the samples; however, the relative abundances of the most dominant genera were significantly different among the samples, and thus they re- flected differences among the structures of the soil microbial community (Table 3). The dominant genera were selected and then used to draw a histogram based on their relative abundances (Fig. 4) to depict the distribution patterns of the bacterial genera among the land-use types. The dominant genera among land-use types had similar distribution patterns, as indicated in Fig. 4. This finding suggested that the land-use conversion of NGM has no distinct effect on the dominant genus compositions of the soil bacterial community. Among these enriched genera, Acidobacteria bacterium, Blastocatella, Sphingomonas, and Bryobacter were 
Top taxonomy distribution at Phylum level

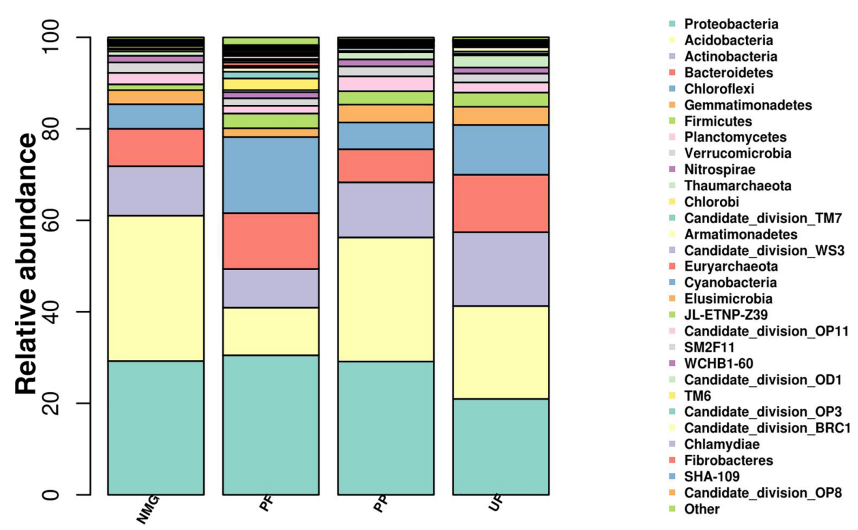

Sample name

Figure 2. Top taxonomic distribution of soil samples at phylum level. NMG: native meadow grassland; UF: 50-year upland field; PF: 26-year paddy field; PP: 34-year poplar plantation.

dominant in all the samples. However, the conversion from NMG to UF, PF, and PP significantly increased the relative abundances of some specific genera $(>1 \%)$, which then became the new dominant taxa: Marmoricola, Ferruginibacter, and Anaerolinea in PF, Arthrobacter, Nocardioides, Massilia, Adhaeribacter, Flavisolibacter, and Rubrobacter in PF, and Chryseolinea in PP, which induced the structural shift of the soil microbial community at the genus level.

\subsection{Relationship between microbial community composition and soil environment factors}

In this study, CCA was conducted to evaluate the relationship between the compositions of the dominant phyla or genera and selected soil properties (soil moisture, electrical conductivity, $\mathrm{pH}$, organic matter, total $\mathrm{N}$ and $\mathrm{P}$, available $\mathrm{N}$ and $\mathrm{P}$, microbial biomass $\mathrm{C}, \mathrm{N}$, and $\mathrm{P}$ ). The results are summarized in Fig. 5. The CCA plots based on the dominant phyla and genera were nearly identical. The overall structures of the dominant phyla or genera in different land-use samples were significantly linked to the selected soil properties. Through CCA ordination, all the samples were classified into three groups. Particularly, NMG and PP samples were grouped into a distinct cluster, while UF and PF formed the other two clusters. The main factors that grouped the NMG and PP samples were $\mathrm{pH}$, organic matter, total $\mathrm{N}$, and microbial biomass C. Meanwhile, cluster UF appeared to be mostly influenced by total $\mathrm{P}$, available $\mathrm{P}$, microbial biomass $\mathrm{P}$, and electrical conductivity. Cluster PF in turn was significantly affected by soil moisture, available $\mathrm{N}$, and microbial biomass N (Fig. 5).

\section{Discussion}

The purpose of the present study was to evaluate the effects of land-use conversion on the composition and structure of soil bacterial communities and explore the relationship between the physical and chemical properties of the soil and specific phyla in the Horqin region. In this regard, UF, PP, and PF were formerly NMG, which is one of the dominant land-use types in the Horqin Sandy Land. Consistent with studies in other areas (Hartman et al., 2008; Wakelin et al., 2008), our results showed significant differences among the structures of the soil bacterial communities in the land-use types. These differences were related to changes in the physical and chemical properties of the soil (especially in $\mathrm{pH}$ and nutrient contents) and thus suggested that the soil properties were significant factors that shape the bacterial community structure. During the conversion from NMG to UF, PF, and $\mathrm{PP}$, the vegetation cover and soil properties were changed according to how the land conversion was managed. Variations in the environment due to land-use conversion have a direct influence on the microbial community inhabiting the soil (Zhang et al., 2014; Mendes et al., 2015). In the Horqin region, the land-use conversion of NMGs usually involves plowing and harrowing the soil and the cultivation of crops or planting trees. This process dramatically altered the soil physical, chemical, and microbiological properties by destroying the vegetation and increasing the rates of organic matter decomposition (Su et al., 2004). Previous studies reported that changes in the soil properties are attributed to cultivation and fertilization of the soil (He et al., 2007; Wang et al., 2012; Shen et al., 2010). Furthermore, the changes in the soils may involve shifts in nutrient contents and soil quality, as the natural grassland or forest plantation areas are expected to accumulate litter deposits, which are relatively more recalcitrant than the crop debris deposited in agricultural areas (Lauber et al., 2008). In an agricultural system, a low input of organic matter, variations in temperature and precipitation, and the management of soils were reported to be related to soil properties and the abundance of organisms (Lauber et al., 2013; Hartmann et al., 2015).

PCoA and CCA showed differences among the structures of the soil microbial communities during the land-use conversion of NMG. CCA was performed on the soil environmental factors and relative abundances of the dominant taxa and indicated that the changes in the environment due to land-use conversion have direct and significant impacts on the community of microorganisms inhabiting the soil. Soil P contents, such as total $\mathrm{P}$, available $\mathrm{P}$, and microbial biomass $\mathrm{P}$, were the most important factors for the microbial community structure in the UF sites. By contrast, the formation of the soil microbial community structures in the PF sites was significantly related to soil moisture, available $\mathrm{N}$, and microbial biomass N (Fig. 5). However, NMG and PP had similar microbial community structures, which were mainly affected by $\mathrm{pH}$, organic matter, total $\mathrm{N}$, and microbial biomass 


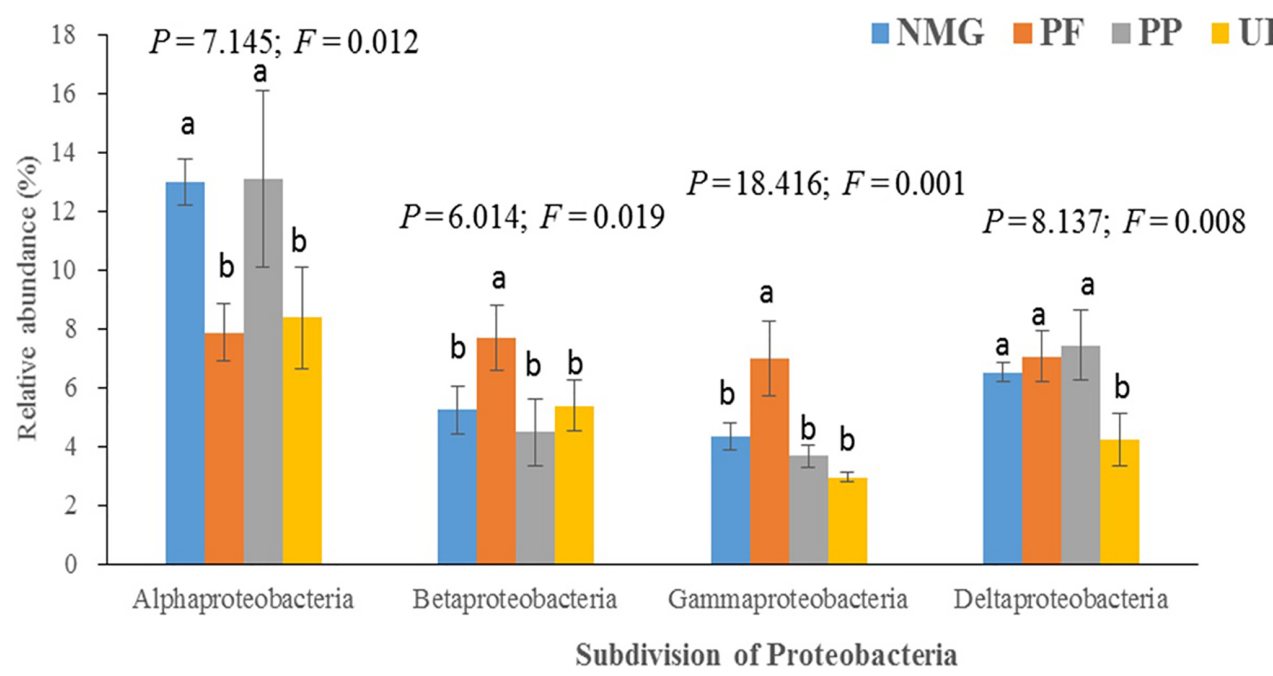

Figure 3. Subdivision distribution of Proteobacteria phylum. NMG: native meadow grassland; UF: 50-year upland field; PF: 26-year paddy field; PP: 34-year poplar plantation.

Table 3. Results of one-way ANOVA for the relative abundance of phyla and genera in different land-use types.

\begin{tabular}{llrllrr}
\hline Order & Phylum & $F$ & $P$ & Genus & $F$ & $P$ \\
\hline 1 & Proteobacteria & 7.58 & 0.010 & Uncultured bacterium & 21.03 & $<0.001$ \\
2 & Acidobacteria & 24.47 & $<0.001$ & Acidobacteria bacterium & 13.60 & 0.002 \\
3 & Actinobacteria & 14.55 & 0.001 & Blastocatella & 14.98 & 0.001 \\
4 & Bacteroidetes & 4.817 & 0.034 & Sphingomonas & 2.843 & 0.105 \\
5 & Chloroflexi & 21.33 & $<0.001$ & Bryobacter & 2.338 & 0.150 \\
6 & Gemmatimonadetes & 21.38 & $<0.001$ & Arthrobacter & 9.194 & 0.006 \\
7 & Firmicutes & 2.219 & 0.163 & Massilia & 11.92 & 0.003 \\
8 & Planctomycetes & 19.09 & 0.001 & Nocardioides & 3.937 & 0.054 \\
9 & Verrucomicrobia & 1.330 & 0.331 & Adhaeribacter & 7.012 & 0.013 \\
10 & Thaumarchaeota & 6.851 & 0.013 & Flavisolibacter & 7.824 & 0.009 \\
11 & Nitrospirae & 0.288 & 0.833 & Chryseolinea & 30.80 & $<0.001$ \\
12 & Chlorobi & 16.60 & 0.001 & Rubrobacter & 4.162 & 0.047 \\
13 & Candidate_division_TM7 & 18.91 & 0.001 & Pontibacter & 8.728 & 0.007 \\
14 & Armatimonadetes & 30.36 & $<0.001$ & Bacillus & 1.616 & 0.261 \\
15 & Candidate_division_WS3 & 0.890 & 0.486 & Nitrospira & 5.724 & 0.022 \\
16 & Cyanobacteria & 6.239 & 0.017 & Haliangium & 1.305 & 0.338 \\
17 & Euryarchaeota & 285.6 & $<0.001$ & Gaiella & 9.340 & 0.005 \\
18 & Elusimicrobia & 2.645 & 0.121 & Marmoricola & 2.819 & 0.107 \\
19 & JL-ETNP-Z39 & 3.748 & 0.060 & Arenimonas & 8.997 & 0.006 \\
20 & Candidate_division_OP11 & 364.2 & $<0.001$ & Streptomyces & 7.261 & 0.011 \\
\hline
\end{tabular}

Phyla and genera are arranged according to relative abundances.

C. Our results demonstrated that $\mathrm{pH}$ was an important factor that shaped the structure of the soil microbial community. Some studies showed that soil $\mathrm{pH}$ is generally related to the compositions and structures of the soil microbial communities across a geographic scale (Högberg et al., 2007; Jesus et al., 2009; Fierer and Jackson, 2006). Mendes et al. (2015) studied the effects of land-use systems on soil bacterial communities in the southeastern region of the Amazon, and they confirmed that $\mathrm{pH}$ is correlated with the structure formation of a bacterial community during land-use alternations.
Wakelin et al. (2008) also found that $\mathrm{pH}$ influences the structural composition and functional capacity of the soil bacterial communities in Australian agricultural soils. The potential causes of this correlation are the following: (1) integration of $\mathrm{pH}$ with other soil physical, chemical, and microbiological properties and (2) a slight variation in the soil $\mathrm{pH}$ that could expose microbes to stress, or in other words, the sensitivity of the microbial cell to environmental change (Fierer and Jackson, 2006). Some studies indicated that several parameters other than $\mathrm{pH}$ and elements (e.g., $\mathrm{Mg}, \mathrm{Al}$, and $\mathrm{Cd}$ ) are also 


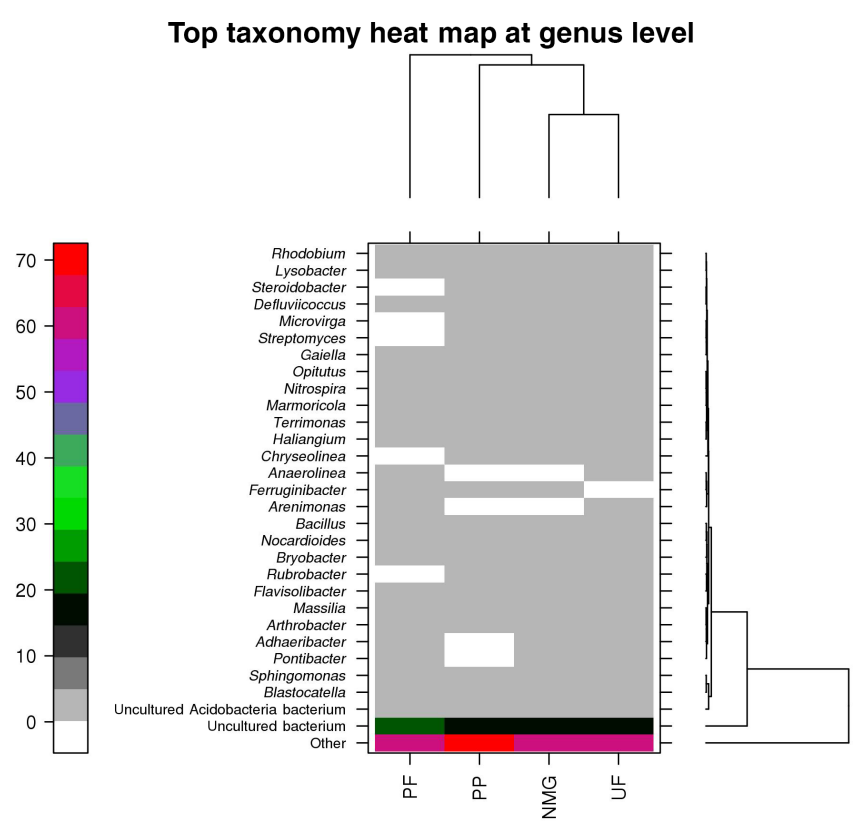

Figure 4. Top taxonomy heat map of soil samples at genus level. NMG: native meadow grassland; UF: 50-year upland field; PF: 26year paddy field; PP: 34-year poplar plantation.

correlated with specific bacterial groups and structural alternation of microbial communities (Pan et al., 2014; Jesus et al., 2009; Mendes et al., 2015).

The vegetation cover might affect the diversity and structure of the soil microbial community because the differences in plant community compositions can contribute to changes in litter quality and quantity, which then alter the content and cycling processes of soil nutrients (Miki et al., 2010). In this study, the four sites differed in terms of vegetation cover. Therefore, differences among the soil properties and structures of the microbial communities in different land-use types can be expected. In the agricultural sites of our study (UF and PF), the cultivation of rice and corn was performed through conventional management, while in NMG and PP, the cultivation was performed through no-tillage management. The long-term cultivation might affect the whole soil community. Souza et al. (2013) showed that the major differences among the soil biodiversity and microbial community structures were associated with tillage management. Differences among the soil structures induced by different tillage systems and land-use conversion influence the structures of microbial communities (Sessitsch et al., 2001; Peixoto et al., 2006). Considering that the four land-use types have the same soil type and the sampling sites were adjacent to each other, we can assume that land-use conversion is a principal driving force that alters the soil properties and microbial community structures. Jangid et al. (2011) investigated the rRNA gene diversity of soil bacteria at two successional gradients with different vegetation, and they found that bacterial diversity remained unchanged in both gradients; their results

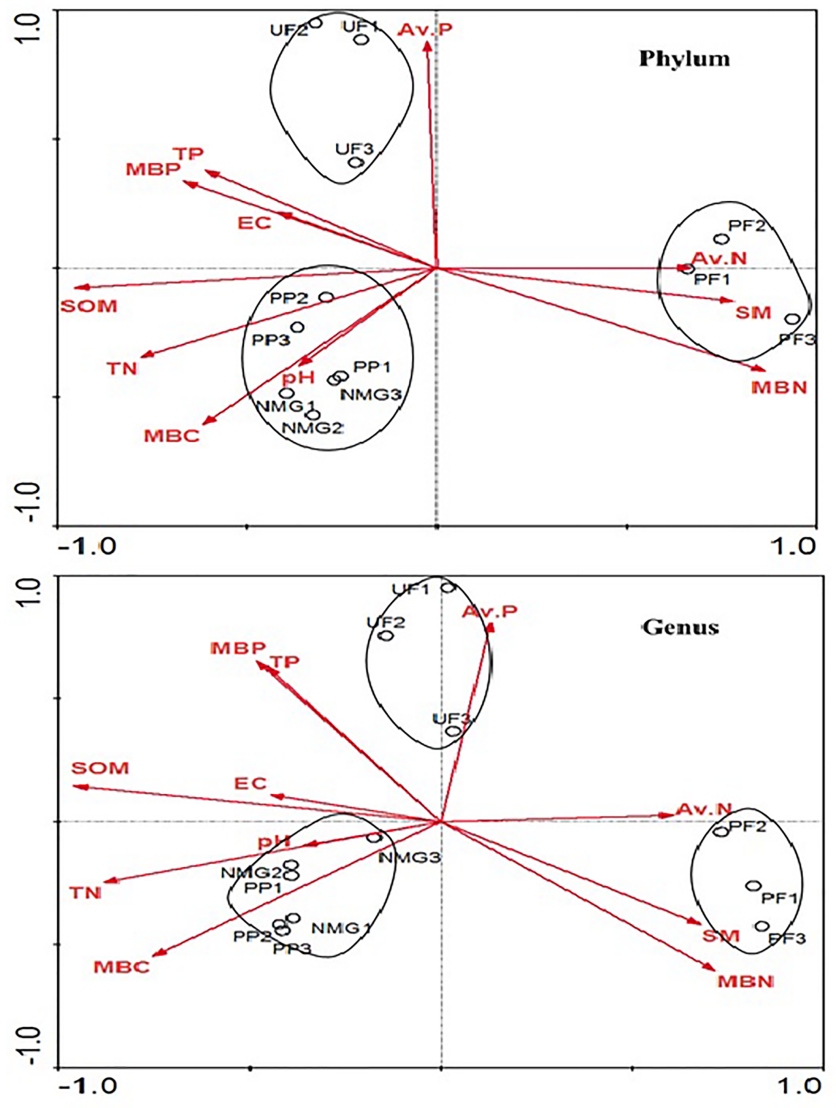

Figure 5. Canonical correspondence analysis (CCA) of soil bacterial community structures and environmental parameters. Arrows indicate the direction and magnitude of environmental parameters associated with bacterial community structures. Abbreviations: Av. $\mathrm{P}$ : available P; SOM: soil organic matter; TP: total P; TN: total $\mathrm{N}$; EC: electrical conductivity; $\mathrm{MBC}$ : microbial biomass $\mathrm{C}$; $\mathrm{MBN}$ : microbial biomss N; MBP: microbial biomass P; NMG: native meadow grassland; UF: 50-year upland field; PF: 26-year paddy field; PP: 34-year poplar plantation.

confirmed that land-use history was the main determinant of the species composition in soil microbial communities rather than soil properties and vegetation. Our results showed that NMG, UF, PF, and PP have nearly the same dominant phyla, genera, and species, although the relative abundances of the taxa were different from one another, which also confirms that the species composition of soil microbial communities was not distinctly affected by land-use change and duration. Similarly, Suleiman et al. (2013) reported that land-use history might affect the present-day structure of the soil microbial community because many highly resilient and resistant microbial populations unrelated to soil type, soil properties, or land use are widely present in the microbial community. Our results showed that the land-use types have nearly the same dominant phyla, genera, and species, although the relative abundances of the taxa were different from one another. For this reason, the influences of land-use conversion were 
suggested to have more quantitative effects than qualitative effects. In other words, the structure of the soil microbial community may be affected by changes in the relative abundances of specific groups. The structure may change in response to land-use conversion, probably because the abundance of specific bacterial taxa sensitive to soil environment variation are extremely low and thus difficult to detect.

The observed phyla are typically present in most soils. Their relative abundances varied among the four land-use types. Hence, land use possibly affected their abundances. Proteobacteria and Acidobacteria were the most abundant phyla in all of the samples. Proteobacteria are commonly described as abundant free-living bacteria in many habitats (Zhou et al., 2004; Drees et al., 2006; Yang et al., 2015). The Acidobacterial community is correlated with soil properties (e.g., $\mathrm{pH}, \mathrm{P}, \mathrm{K}, \mathrm{Ca}, \mathrm{Mg}$, and $\mathrm{Al}$ contents), and its abundance can be altered by soil type and land-use change (Navarrete et al., 2013; Mendes et al., 2015). Our study showed a decrease in the relative abundance of the Acidobacteria group during the conversion of NMG to UF, PF, and PP. At the genus level, the relative abundance of the dominant genera (Acidobacteria bacterium, Blastocatella, and Sphingomonas) also decreased during this process. This effect indicated that bacterial community structures were altered during land-use conversion.

Our results confirm that land-use conversion directly alters soil properties and microbial community structures in soil. These changes may produce potential effects on the ecological functions of meadow grassland ecosystems. However, the effect of land-use conversion on the functional profile of soil microbes remains unknown. Therefore, further studies on microbial functional profiles in Horqin soils should be performed to understand the function of soil microbes and to evaluate the sustainability of land-use systems.

\section{Conclusions}

1. In this study, land-use conversion in the NMG of the Horqin Sandy Land elicits a distinct effect on the physical and chemical parameters of soil and the structure of soil bacterial communities. Differences among the structures of soil microbial communities are caused by land-use change and variability in land management practices, which directly influence soil physical, chemical, and microbiological properties.

2. Soil properties, including organic matter, $\mathrm{pH}$, total $\mathrm{N}$, total $\mathrm{P}$, available $\mathrm{N}$ and $\mathrm{P}$, and microbial biomass $\mathrm{C}, \mathrm{N}$, and $\mathrm{P}$, directly affect microbial community structures. The effects of land-use change on the structure of the soil microbial community are mostly quantitative rather than qualitative. For example, their structure is affected by changing the relative abundances of specific groups, and their structure becomes altered in response to landuse conversion.
Data availability. High-throughput Illumina MiSeq sequencing of microbial 16S rDNA was performed by Genewiz Biotechnology Co., Ltd, Suzhou, China. All data used in this study to generate the figures are freely available upon request by contacting the corresponding author at caochengyou@ mail.neu.edu.cn.

Competing interests. The authors declare that they have no conflict of interest.

Acknowledgements. This work was supported by funds from the National Key Research and Development Program of China (grant no. 2016YFC0500803) and the National Natural Science foundation of China (41371505). The authors would like to express their gratitude to the members of the Wulanaodu Station of Desertification Research under the Chinese Academy of Sciences for their technical assistance.

Edited by: Marc Oliva

Reviewed by: two anonymous referees

\section{References}

Baath, E. and Anderson, T. H.: Comparison of soil fungal/bacterial ratios in a $\mathrm{pH}$ gradient using physiological and PLFA-based techniques, Soil Biol. Biochem., 35, 955-963, 2003.

Berg, J., Brandt, K. K., Al-Soud, W. A., Holm, P. E., Hansen, L. H., Sørensen, S. J., and Nybroe, O.: Selection for Cu-tolerant bacterial communities with altered composition, but unaltered richness, via long-term $\mathrm{Cu}$ exposure, Appl. Environ. Microb., 78, 7438-7446, 2012.

Brookes, P. C., Powlson, D. S., and Jenkinson, D. S.: Measurement of microbial biomass phosphorus in soil, Soil Biol. Biochem., 14, 319-329, 1982.

Bruce, K. D., Jones, T. H., Bezemer, T. M., Thompson, L. J., and Ritchie, D. A.: The effect of elevated atmospheric carbon dioxide levels on soil bacterial communities, Glob. Change Biol., 6, 427434, 2000.

Cao, C. Y., Jiang, D. M., Zhu, L. H., and Nan, Y. H.: Degradation and diversity changes of meadow grassland in Keerqin Sandy Land, Acta Pratacultuae Sinica, 15, 18-26, 2006.

Cao, C. Y., Jiang, D. M., Teng, X. H., Jiang, Y., Liang, W. J., and Cui, Z. B.: Soil chemicaland microbiological properties along a chronosequence of Caragana microphylla Lam. plantations in the Horqin Sandy Land of Northeast China, Appl. Soil Ecol., 40, 78-85, 2008.

Drees, K. P., Neilson, J. W., Betancourt, J. L., Quade, J., Henderson, D. A., Pryor, B. M., and Maier, R. M.: Bacterial community structure in the hyperarid core of the Atacama Desert, Chile, Appl. Environ. Microb., 72, 7902-7908, 2006.

Fierer, N. and Jackson, R. B.: The diversity and biogeography of soil bacterial communities, P. Natl. Acad. Sci. USA, 103, 626631, 2006.

Golebiewski, M., Deja-Sikora, E., Cichosz, M., Tretyn, A., and Wrobel, B.: 16S rDNA pyrosequencing analysis of bacterial community in heavy metals polluted soils, Microb. Ecol., 67, 635-647, 2014. 
Griffiths, R. I., Thomson, B. C., James, P., Bell, T., Bailey, M., and Whiteley, A. S.: The bacterial biogeography of British soils, Environ. Microbiol., 13, 1642-1654, 2011.

Hartman, W. H., Richardson, C. J., Vilgalys, R., and Bruland, G. L.: Environmental and anthropogenic controls over bacterial communities in wetland soils, P. Natl. Acad. Sci. USA, 105, 1784217847, 2008.

Hartmann, M., Howes, C. G., VanInsberghe, D., Yu, H., Bachar, D., Christen, R., Henrik, N. R., Hallam, S. J., and Mohn, W. W.: Significant and persistent impact of timber harvesting on soil microbial communities in Northern coniferous forests, ISME J., 6, 2199-2218, 2012.

Hartmann, M., Frey, B., Mayer, J., Mäder, P., and Widmer, F.: Distinct soil microbial diversity under long-term organic and conventional farming, ISME J., 9, 1177-1194, 2015.

He, J. Z., Shen, J. P., Zhang, L. M., Zhu, Y. Q., Zheng, Y. M., Xu, M. G., and Di, H. J.: Quantitative analyses of the abundance and composition of ammonia-oxidizing bacteria and ammoniaoxidizing archaea of a Chinese upland red soil under long-term fertilization practices, Environ. Microbiol., 9, 2364-2374, 2007.

He, J. Z., Zheng, Y., Chen, C. R., He, Y. Q., and Zhang, L. M.: Microbial composition and diversity of an upland red soil under long-term fertilization treatments as revealed by culturedependent and culture-independent approaches, J. Soil. Sediment., 8, 349-358, 2008.

Högberg, M. N., Högberg, P., and Myrold, D. D.: Is microbial community composition in boreal forest soils determined by $\mathrm{pH}$, C-to-N ratio, the trees, or all three?, Oecologia, 150, 590-601, 2007

Holland, T. C., Bowen, P. A., Bogdanof, C. P., Lowery, T. D., Shaposhnikova, O., Smith, S., and Hart, M. M.: Evaluating the diversity of soil microbial communities in vineyards relative to adjacent native ecosystems, Appl. Soil Ecol., 100, 91-103, 2016.

Hugerth, L. W., Wefer, H. A., Lundin, S., Jakobsson, H. E., Lindberg, M., Rodin, S., Engstrand, L., and Andersson, A. F.: DegePrime, a program for degenerate primer design for broadtaxonomic-range PCR in microbial ecology studies, Appl. Environ. Microb., 80, 5116-5123, 2014.

Institute of Soil Science, Chinese Academy of Sciences (ISSCAS): Physical and Chemical Analysis Methods of Soils. Shanghai Science Technology Press, Shanghai, 7-59, 1978 (in Chinese).

Jangid, K., Williams, M. A., Franzluebbers, A. J., Schmidt, T. M., Coleman, D. C., and Whitman, W. B.: Land-use history has a stronger impact on soil microbial community composition than aboveground vegetation and soil properties, Soil Biol. Biochem., 43, 2184-2193, 2011.

Jenkinson, D. S. and Powlson, D. S.: The effects of biosidal treatments on metabolism in soil V. A method for measuring soil biomass, Soil Biol. Biochem., 8, 209-213, 1976.

Jesus, E. D., Marsh, T. L., Tiedje, J. M., and Moreira, F. M. D.: Changes in land use alter the structure of bacterial communities in western Amazon soils, ISME J., 3, 1004-1011, 2009.

Johnson, M. J., Lee, K. Y., and Scow, K. M.: DNA fingerprinting reveals links among agricultural crops, soil properties, and the composition of soil microbial communities, Geoderma, 114, 279-303, 2003.

Kuramae, E. E., Yergeau, E., Wong, L. C., Pijl, A. S., van Veen, J. A., and Kowalchuk, G. A.: Soil characteristics more strongly influence soil bacterial communities than land-use type, FEMS Microbiol. Ecol., 79, 12-24, 2012.

Lauber, C. L., Strickland, M. S., Bradford, M. A.,and Fierer, N.: The influence of soil properties on the structure of bacterial and fungal communities across land-use types, Soil Biol. Biochem., 40, 2407-2415, 2008.

Lauber, C. L., Ramirez, K. S., Aanderud, Z., Lennon, J., and Fierer, N.: Temporal variability in soil microbial communities across land-use types, ISME J., 7, 1641-1650, 2013.

Lin, Y. T., Jangid, K., Whitman, W. B., Coleman, D. C., and Chiu, C. Y.: Change in bacterial community structure in response to disturbance of natural hardwood and secondary coniferous forest soils in central Taiwan, Microb. Ecol., 61, 429-437, 2011.

Liu, J., Hua, Z. S., Chen, L. X., Kuang, J. L., Li, S. J., Shu, W. S., and Huang, L. N.: Correlating microbial diversity patterns with geochemistry in an extreme and heterogeneous environment of mine tailings, Appl. Environ. Microb., 80, 3677-3686, 2014.

Mendes, L. W., Brossi, M. J. D., Kuramae, E. E., and Tsai, S. M.: Land-use system shapes soil bacterial communities in Southeastern Amazon region, Appl. Soil. Ecol., 95, 151-160, 2015.

Miki, T., Ushio, M., Fukui, S., and Kondoh, M.: Functional diversity of microbial decomposers facilitates plant coexistence in a plant-microbe-soil feedback model, P. Natl. Acad. Sci. USA, 107, 14251-14256, 2010.

Murty, D., Kirschbaum, M. U. F., McMurtrie, R. E., and McGilvray, A.: Does conversion of forest to agricultural land change soil carbon and nitrogen? A review of the literature, Glob. Change Biol., 8, 105-123, 2002.

Navarrete, A. A., Kuramae, E. E., de Hollander, M., Pijl, A. S., van Veen, J. A., and Tsai, S. M.: Acidobacterial community responses to agricultural management of soybean in Amazon forest soils, FEMS Microbiol. Ecol., 83, 607-621, 2013.

Nishimura, S., Yonemura, S., Sawamoto, T., Shirato, Y., Akiyama, H., Sudo, S., and Yagi, K.: Effect of land use change from paddy rice cultivation to upland crop cultivation on soil carbon budget of a cropland in Japan, Agr. Ecosyst. Environ., 125, 9-20, 2008.

Pabst, H., Kuhnel, A., and Kuzyakov, Y.: Effect of land-use and elevation on microbial biomass and water extractable carbon in soils of Mt. Kilimanjaro ecosystems, Appl. Soil. Ecol., 67, 10 19, 2013.

Pan, Y., Cassman, N., de Hollander, M., Mendes, L. W., Korevaar, H., Geerts, R. H. E. M., van Veen, J. A., and Kuramae, E. E.: Impact of long-term N, P, K and NPK fertilization on the composition and potential functions of the bacterial community in grassland soil, FEMS Microbiol. Ecol., 90, 195-205, 2014.

Peixoto, R. S., Coutinho, H. L. C., Madari, B., Machado, P. L. O. A., Rumjanek, N. G., van Elsas, J. D., Seldin, L., and Rosado, A. S.: Soil aggregation and bacterial community structure as affected by tillage and cover cropping in the Brazilian Cerrados, Soil Till. Res., 90, 16-28, 2006.

Portune, K. J., Perez, M. C., Alvarez-Hornos, F. J., and Gabaldon, C.: Investigating bacterial populations in styrene-degrading biofilters by $16 \mathrm{~S}$ rDNA tag pyrosequencing, Appl. Microbiol. Biot., 99, 3-18, 2014.

Quince, C., Lanzen, A., Curtis, T. P., Davenport, R. J., Hall, N., Head, I. M., Read, L. F., and Sloan, W. T.: Accurate determination of microbial diversity from 454 pyrosequencing data, Nat. Methods, 6, 639-641, 2009. 
Rahman, M. H., Okubo, A., Sugiyama, S., and Mayland, H. F.: Physical, chemical and microbiological properties of an Andisol as related to land use and tillage practice, Soil Till. Res., 101, 10-19, 2008.

Ran, J. J., Ji, M. X., Huang, J. P., Qi, Y. L., Li, Y., and Guan, X. D.: Characteristics and factors of climate change in arid and semiarid areas over Northern China in the recent 60 years, Journal of Lanzhou University (Natural Sciences), 50, 46-53, 2014 (in Chinese with English abstract).

Ren, G. D., Zhang, H. Y., Lin, X. G., Zhu, J. G., and Jia, Z. J.: Response of phyllosphere bacterial communities to elevated $\mathrm{CO}_{2}$ during rice growing season, Appl. Microbiol. Biot., 98, 94599471, 2014.

Sala, O. E., Chapin, F. S., Armesto, J. J., Berlow, E., Bloomfield, J., Dirzo, R., Huber-Sanwald, E., Huenneke, L. F., Jackson, R. B., Kinzig, A., Leemans, R., Lodge, D. M., Mooney, H. A., Oesterheld, M., Poff, N. L., Sykes, M. T., Walker, B. H., Walker, M., and Wall, D. H.: Biodiversity-global biodiversity scenarios for the year 2100, Science, 287, 1770-1774, 2000.

Schloss, P. D., Westcott, S. L., Ryabin, T., Hall, J. R., Hartmann, M., Hollister, E. B., Lesniewski, R. A., Oakley, B. B., Parks, D. H., and Robinson, C. J.: Introducing mothur: open-source, platform independent, community-supported software for describing and comparing microbial communities, Appl. Microbiol. Biot., 75, 7537-7541, 2009.

Sessitsch, A., Weilharter, A., Gerzabek, M. H., Kirkchmann, H., and Kandeler, E.: Microbial population structures in soil particle size fractions of a long-term fertilizer field experiments, Appl. Environ. Microb., 67, 4215-4224, 2001.

Shen, J. P., Zhang, L. M., Guo, J. F., Ray, J. L., and He, J. Z.: Impact of long-term fertilization practices on the abundance and composition of soil bacterial communities in Northeast China, Appl. Soil. Ecol., 46, 119-124, 2010.

Shi, Y. W., Yang, H. M., Zhang, T., Sun, J., and Lou, K.: Illuminabased analysis of endophytic bacterial diversity and space-time dynamics in sugar beet on the north slope of Tianshan Mountain, Appl. Microbiol. Biot., 98, 6375-6385, 2014.

Singh, B., Crippen, T. L., Zheng, L. Y., Fields, A. T., Yu, Z., Ma, Q., Wood, T. K., Dowd, S. E., Flores, M., Tomberlin, J. K., and Tarone, A. T.: A metagenomic assessment of the bacteria associated with Luciliasericata and Luciliacuprina (Diptera: Calliphoridae), Appl. Microbiol. Biot., 99, 869-883, 2014.

Souza, R. C., Cantão, M. E., Vasconcelos, A. T. R., Nogueira, M. A., and Hungria, M.: Soil metagenomics reveals differences under conventional and no-tillage with crop rotation and succession, Appl. Soil. Ecol., 72, 49-61, 2013.

Steenwerth, K. L., Jackson, L. E., Calderon, F. J., Stromberg, M. R., and Scow, K. M.: Soil microbial community composition and land use history in cultivated and grassland ecosystems of coastal California, Soil Biol. Biochem., 34, 1599-1611, 2002.

Su, Y., Zhao, H., Zhang, T., and Zhao, X.: Soil properties following cultivation and non-grazing of a semi-arid sandy grassland in northern China, Soil Till. Res., 75, 27-36, 2004.

Suleiman, A. K. A., Manoeli, L., Boldo, J. T., Pereira, M. G., and Roesch, L. F. W.: Shifts in soil bacterial community after eight years of land-use change, Syst. Appl. Microbiol., 36, 137-144, 2013.
Thomson, B. C., Ostle, N., McNamara, N., Bailey, M. J., Whiteley, A. S., and Griffiths, R. I.: Vegetation affects the relative abundances of dominant soil bacterial taxa and soil respiration rates in an upland grassland soil, Microb. Ecol., 59, 335-343, 2010.

Thomson, B. C., Tisserant, E., Plassart, P., Uroz, S., Griffiths, R. I., Hannula, S. E., Buee, M., Mougel, C., Ranjard, L., Van Veen, J. A., Martin, F., Bailey, M. J., and Lemanceau, P.: Soil conditions and land use intensification effects on soil microbial communities across a range of European field sites, Soil Biol. Biochem., 88, 403-413, 2015.

Wakelin, S. A., Macdonald, L. M., Rogers, S. L., Gregg, A. L., Bolger, T. P., and Baldock, J. A.: Habitat selective factors influencing the structural composition and functional capacity of microbial communities in agricultural soils, Soil Biol. Biochem., 40, 803813, 2008.

Wallenius, K., Rita, H., Mikkonen, A., Lappi, K., Lindstrom, K., Hartikainen, H., Raateland, A., and Niemi, R. M.: Effects of land use on the level, variation and spatial structure of soil enzyme activities and bacterial communities, Soil Biol. Biochem., 43, 1464-1473, 2011.

Wang, B., Xue, S., Liu, G. B., Zhang, G. H., Li, G., and Ren, Z. P.: Changes in soil nutrient and enzyme activities under different vegetations in the Loess Plateau area, Northwest China, Catena, 92, 186-196, 2012.

Wang, Q., Garrity, G. M., Tiedje, J. M., and Cole, J. R.: Naive Bayesian classifier for rapid assignment of rRNA sequences into the new bacterial taxonomy, Appl. Microbiol. Biot., 73, 52615267, 2007.

Yang, C. Y., Li, Y., Zhou, B., Zhou, Y. Y., Zheng, W., Tian, Y., Van Nostrand, J. D., Wu, L. Y., He, Z. L., Zhou, J. Z., and Zheng, T. L.: Illumina sequencing-based analysis of free-living bacterial community dynamics during an Akashiwo sanguine bloom in Xiamen Sea, China, Sci Rep., 5, 8476, https://doi.org/10.1038/srep08476, 2015.

Zhang, M., Wu, J., and Tang, Y.: The effects of grazing on the spatial pattern of elm (Ulmus pumila L.) in the sparse woodland steppe of Horqin Sandy Land in northeastern China, Solid Earth, 7, 631637, https://doi.org/10.5194/se-7-631-2016, 2016.

Zhang, Y., Cao, C. Y., Peng, M., Xu, X. J., Zhang, P., Yu, Q. J., and Sun, T.: Diversity of nitrogen-fixing, ammonia-oxidizing, and denitrifying bacteria in biological soil crusts of a revegetation area in Horqin Sandy Land, Northeast China, Ecol. Eng., 71, 71-79, 2014.

Zhang, Y., Cao, C., Guo, L., Wu, Q., and Cui, Z.: Soil properties, bacterial community composition, and metabolic diversity responses to soil salinization of a semiarid grassland in northeast China, J. Soil Water Conserv., 70, 110-120, 2015.

Zhao, D. Y., Huang, R., Zeng, J., Yu, Z. B., Liu, P., Cheng, S. P., and $\mathrm{Wu}, \mathrm{Q}$. L.: Pyrosequencing analysis of bacterial community and assembly in activated sludge samples from different geographic regions in China, Appl. Microbiol. Biot., 98, 9119-9128, 2014.

Zhou, J. Z., Xia, B. C., Huang, H., Palumbo, A. V., and Tiedje, J. M.: Microbial diversity and heterogeneity in sandy subsurface soils, Appl. Microbiol. Biot., 70, 1723-1734, 2004. 